Teaching \& Learning (2015) 10(1), 1-20

\title{
School-based Physical Activity: Planning with student motivation in mind
}

\author{
JOE BARRETT
}

Brock University

\begin{abstract}
Central to providing rich and diverse PA opportunities in schools are our classroom teachers. Regardless of generalist or specialist training in health and physical education, all of our Ontario teachers play a vital role in providing opportunities for children and youth to learn through PA. This paper (a) positions student participation in school-based PA as an essential public health outcome, (b) explores barriers affecting teachers' efforts to provide school-based PA, and (c) offers teachers one potential macro planning and instructional solution to address a single barrier-the challenge associated with planning for student motivation in school-based PA settings. Keller's (1987) influential ARCS model of motivational design provides the foundation for the proposed solution. An adapted version, the ARCS School-Based PA model, is presented. The adapted model offers considerations and sample category success strategies that could be embedded in teachers' current school-based PA planning and instructional practices to support the development of school-based PA programming that is firmly grounded in learner motivation and needs.
\end{abstract}

\section{Acknowledgement}

I would like to recognize and thank my former graduate education student, Dean Majierowski, for introducing me to his interpretations of the great work of Dr. Keller. Those

early introductions have led to my further exploration of the use of Dr. Keller's ARCS model within the context of physical and health education teacher education. Thank you Dean.

\section{Introduction}

Over the last decade, the Ontario Ministry of Education has endeavoured to make health and physical education (HPE) and school-based physical activity more accessible and meaningful for children and youth. These efforts have been realized primarily through (a) revising and promoting mandatory HPE curricular learning outcomes, and (b) introducing Daily Physical Activity (DPA) policy requirements (Ministry of Education, 2005,2010 ). From a policy standpoint, the provincial government has taken a very public stance outlining a mandate to succeed in making publicly funded schools healthier places for 21st-century students to learn and achieve partly through providing mandated school- 
based physical activity (PA) programming (Ministry of Education, 2005, 2010). But although their efforts are to be supported and even applauded, evidence continues to suggest that a divide remains between school-based PA policy requirements and efforts to ensure regular student participation in publicly funded schools (Barrett, 2011; Lodewyk, \& Pybus, 2013; Dwyer et al., 2006). In response, this paper will (a) position student participation in school-based PA as an essential public health outcome, (b) explore barriers affecting teachers' efforts to provide school-based PA, and (c) offer teachers one potential macro planning and instructional solution to address a single barrier-the challenge associated with planning for student motivation in school-based PA settings.

\section{Need for Renewed Focus on School-based PA}

For decades, Canadian public health initiatives have attempted to target PA behaviour changes as a method for maintaining or improving the overall health and wellbeing of constituent citizens. Although PA's benefits are well known, certain barriers are universally reported (e.g., lack of time, motivation), whereas others (e.g., attitudes toward exercise, lack of facilities) vary with culture and population differences (Sorensen \& Gill, 2008). What we do know is that Canadians continue to struggle to prioritize PA participation as evidenced by the ever-increasing proportion of the population considered overweight or obese (Public Health Agency of Canada, 2011; Shields, Carroll, \& Ogden, 2011). As Sallis and colleagues (2006) have noted, the continued proliferation of sedentary lifestyles may be a result of our 21st-century daily routines:

Trends that facilitate extensive use of cars and electronic entertainment, zoning codes that require building auto-dependent suburbs, limited investment in pedestrian and cycling facilities, computer-centric work environments, proliferation of labor-saving devices, and fire codes that required stairways to be closed are plausible explanations of the development of sedentary lifestyles. (p. 300)

In consequence of our emergent sedentary behaviours, data indicate that physical inactivity is now situated as the fourth-leading risk factor for global mortality and a principal cause of numerous cancers, cardiovascular disease, and diabetes (World Health Organization, 2010). 
What does this have to do with schools? Public schools in Ontario could play a vital role in a multidimensional approach to promoting and developing healthy and lifelong PA activity patterns (Douglas, Lu, \& Barrett, 2013). Since, school-aged children and youth between ages 4 and 17 spend much of their time in school settings. For most of our constituent children, Ontario public schools provide unparalleled access to facilities, equipment, and instruction that support a variety of PA opportunities for all children regardless of race, ethnicity, gender, or socioeconomic status (Barrett, 2013; Kahn et al., 2002), thus making schools ideal places and spaces for PA interventions. Although the research examining the relationship between patterns of PA established in childhood and adolescence and those in adulthood are inconsistent, it can be reasonably suggested that children and adolescents may be more likely to continue PA behaviours that are enjoyable, fun, and socially oriented (Public Health Agency of Canada, 2011).

\section{Teaching School-based PA: Role of the Teacher}

Central to providing rich and diverse PA opportunities in schools are our classroom teachers. Regardless of generalist or specialist training in HPE, all of our Ontario teachers play a vital role in providing opportunities for children and youth to learn through PA. Studies continue to provide convincing evidence that classroom teachers realize the important role that school-based PA programming can play in the healthy development of children and youth (Alberta Education, 2008; Barrett, 2011, 2013 Morgan \& Hansen, 2008).

Yet despite strong beliefs in and intent to teach school-based PA, teachers continue to identify and encounter considerable barriers in teaching physical education (PE) and PA programs, including challenges associated with student motivation, lack of teaching selfefficacy, lack of instructional time, curricular tensions, inadequate resources, and a perceived lack of training and preparation (Hill \& Brodin, 2004; Morgan, 2008; Morgan \& Bourke, 2005). Many of these barriers, encountered by elementary teachers in particular, have been correlated with strongly held perceptions of both PE/PA programming and low self-efficacy about their ability to plan and deliver student-centred PA instruction (Doolittle, Dodds, \& Placek, 1993; Gurvitch \& Metzler, 2009; Morgan, 2008). After addressing the many barriers and factors influencing the planning, delivery, and 
participation in school-based PA, we can begin to explore potential solutions made up of multiple and concurrent strategies.

This paper offers teachers an approach that can be utilized as part of a comprehensive set of strategies designed to influence planning, delivery, and participation in school-based physical activity. In particular, an approach to planning and instructing in school-based PA with student motivation in mind will be outlined. This approach asks teachers to consider setting aside intuitive tendencies and tacit understandings in favour of a more systematic approach to preparing and teaching engaging, relevant, and meaningful school-based PA experiences with student motivation in mind.

Ontario's teachers will have encountered several motivational theories including achievement goal theory, self-determination theory, self-efficacy theory (Ames, 1992; Bandura, 1977; Deci \& Ryan, 1985). More importantly, many will have explored the relevant importance of these theories as part of their teacher education training and ongoing professional development in education. In the context of school-based PA teaching, it is inevitable that teachers will witness the consistent role played by motivation in their students' daily participation and performance (Good \& Brophy, 2000). But is it reasonable to assume that teachers have the time and understanding to apply these various theories in their PA teaching practices? Ames (1990) has suggested that this assertion may not be fair:

We cannot assume, however, that teachers are prepared to translate these ideas into practice-we give too little attention to how motivational concepts interface with the instructional program, too little attention to how the social context of the classroom can undermine or facilitate the development of students' motivation to learn, and too little attention to how motivational principles relate to each otherthen hope that the teacher's intuition has somehow been enlightened and the teacher will be able to apply this knowledge. (p. 415)

Regrettably, there is a paucity of evidence pertaining to teachers who are responsible for school-based PA and their understanding and application of motivational theories. Rather, what we find are numerous studies exploring the relationship between 
student motivational profiles or levels of motivation and essential school-based physical activity outcomes such as achievement, effort, and enjoyment (Boiche, Sarrazin, Grouzet, Pelletier, \& Chanal, 2008; Ntoumanis, 2001, 2005; Yli-Piipari, Wang, Jaakkola, \& Liukkonen, 2012). As an example, Boiche et al. (2008) found that students' motivational profiles were significantly linked to student achievement in school-based PA regardless of students' initial skills and abilities present at the outset of the activity teaching. Those students with displayed a self-determined profile, were more likely to perform better in the final performance tasks. Related to achievement, evidence has also suggested that changes in students' intrinsic motivation are positively associated with changes in student effort and intent to exercise in school-based PA (Hagger, Chatzisarantis, Barkoukis, Wang, \& Baranowski, 2005; Taylor, Ntoumanis, Standage, \& Spray, 2010).

In view of the aforementioned role that public schools can play in a multidimensional approach to promoting and developing healthy and lifelong PA activity patterns, students' motivational experiences in school-based PA are also widely regarded as a significant factor impacting enjoyment in PA. As an example, research by Zhang (2009) revealed that motivation (intrinsic) was positively related to students' physical activity participation, effort, and enjoyment while student motivation was negatively associated with effort and enjoyment in school-based PA.

The above noted studies, and many others, have made valuable contributions to our theoretical understandings of student motivation across a variety of school-based physical activity contexts. That said, there continues to be, to my knowledge, few approaches that help teachers synthesize the available motivation research in such a way that can inform planning and teaching decisions in practice and on a daily basis. School-based PA teachers may benefit from the exploration of a modified and practically oriented model based on Keller's (1979, 1983, 2000) ARCS Model of Motivational Design. The modified model may offer school-based PA teachers a systematic approach to preparing and teaching engaging, relevant, and meaningful experiences with student motivation in mind.

\section{The ARCS Model}

In an effort to help teachers synthesize relevant motivational theories and find ways to identify, understand, and solve student motivation problems, $\operatorname{Keller}(1979,1983)$ 
proposed the so-called ARCS (attention, relevance, confidence, satisfaction) model. The established model takes a holistic view of motivation concepts and theories and could offer a systematic approach to preparing and teaching school-based PA with student motivation in mind (Keller, 2008). The ARCS model comprises four conceptual categories or conditions: (a) gathering and maintaining students' attention, (b) helping students to explore and find relevance in instructional activities, (c) providing learning opportunities that foster students' confidence in their own abilities, and (d) celebrating student achievement with the aim of helping students to find satisfaction in their efforts. Additionally, the model provides a design process for teachers to consider. The process includes pre-instructional analysis, analysis, and instructional planning for motivation, instruction, and reflection based on the instructional planning and teaching (Keller, 1987; Keller \& Suzuki, 2004).

Comprehensively meeting students' learning needs in school-based PA settings requires understanding their motivational needs through an external, tangible, and systematic approach. The ARCS model, inclusive of its categories and design process, could provide teachers a systematic approach that may be integrated within existing instructional planning practices to support the development of school-based PA programming grounded in learner motivation and needs.

\section{Design with Motivation in Mind-Modified ARCS School-Based PA Model}

Here I interpret the ARCS model design process $(1987,2000)$ and conceptual categories developed by Keller from a school-based PA perspective. From those interpretations, I offer a modified ARCS school-based PA (ARCS-sbPA) model process designed to support teachers' efforts to develop learner-centred school-based PA programming and instruction. I strongly believe that Keller's model can offer an approach to achieving praxis--making theories of motivation lived, accessible and core to daily planning and teaching decisions with student motivation in mind. The need to modify the ARCS model is derived out of what I believe are unique and essential characteristics present in school-based physical activity teaching (educating through the physical, fundamental movement skill development, game techniques and strategies, greater emphasis on performance -based assessments, effort on display in a variety of unique 
learning environments, and concepts of enjoyment, confidence, competence, and capacity building across a wide range of physical activities). The modified ARCS school-based PA model (ARCS-sbPA) is presented in a form, with its familiar and discipline specific language, with the aim of assisting school-based PA teachers in their efforts to plan for meaningful school-based PA experiences with learners' motivational needs in mind.

\section{Expanding the Scope of Diagnostic Assessments}

Diagnostic assessments take place prior to instruction and provide the teacher with valuable information pertaining to students' prior knowledge, level of ability, gaps in learning, and misconceptions. With this knowledge in hand, teachers are able to "modify and differentiate teaching and learning activities based on students' needs" (Ministry of Education, 2011, p. 25). In PA settings, diagnostic assessments could be expanded to include an assessment of student motivation. The following four questions could be used in early diagnostic assessment tools alongside measures of students' prior knowledge, skills, and ability.

1. Have I explored the value that students will place on this lesson/activity/unit?

2. Am I aware of students' interest in this lesson/activity/unit?

3. Have I identified their concerns associated with participating in the lesson/activity/unit prior to instruction?

4. Do I know what my students are looking to take away from their participation in the lesson/activity/unit?

Teachers and students could address these questions using a variety of methods, including large- and small-group discussions, individual student conferencing, exit cards, questioning, self-assessments, and graphic organizers. Doing so could lead to carefully designed school-based PA experiences that may have an impact on students' effort, achievement, and enjoyment.

\section{Planning With Motivation in Mind}

Guided by a universal design-for-learning framework, Ontario's teachers plan for student learning using a variety of instructional strategies and mediums to try to meet the 
student learning needs of all. Additionally, teachers plan to provide their students with multiple and varied opportunities to demonstrate or share their learning in various ways. To further strengthen their planning efforts, school-based PA teachers could bring motivational considerations to the fore by analyzing the student learning and motivation information collected during their diagnostic efforts; they could then begin to synthesize meaningful learning goals, assessment strategies, and instructional plans that differentially address the learning and motivational needs of their students. The following four steps could be incorporated into existing planning practices to address student motivational needs:

1. Analyze the motivation and student learning data collected via the diagnostic assessment as understanding the potential relationship between student learning and student motivation may yield valuable insight into student needs.

2. Brainstorm success strategies by category (attention, relevance, confidence, satisfaction) to address specific motivation problems identified in the analysis of the diagnostic assessment. Tables 1 through 4 provide teachers with sample success strategies by category.

3. Develop lesson/activity/unit plans that include, as a foundation, developed motivational strategies, as a component of differentiated instruction targeting success for everyone in school-based PA settings.

4. Share plans and strategies with students. Doing so may provide the teacher with valuable feedback, while providing students a view into "planning for instruction" decisions made by the teacher. 
Table 1

Attending to Attention in School-based PA

\begin{tabular}{|c|c|}
\hline $\begin{array}{l}\text { ARCS-sbPA } \\
\text { Conceptual } \\
\text { Category }\end{array}$ & Sample success strategies for school-based PA settings \\
\hline Attention & 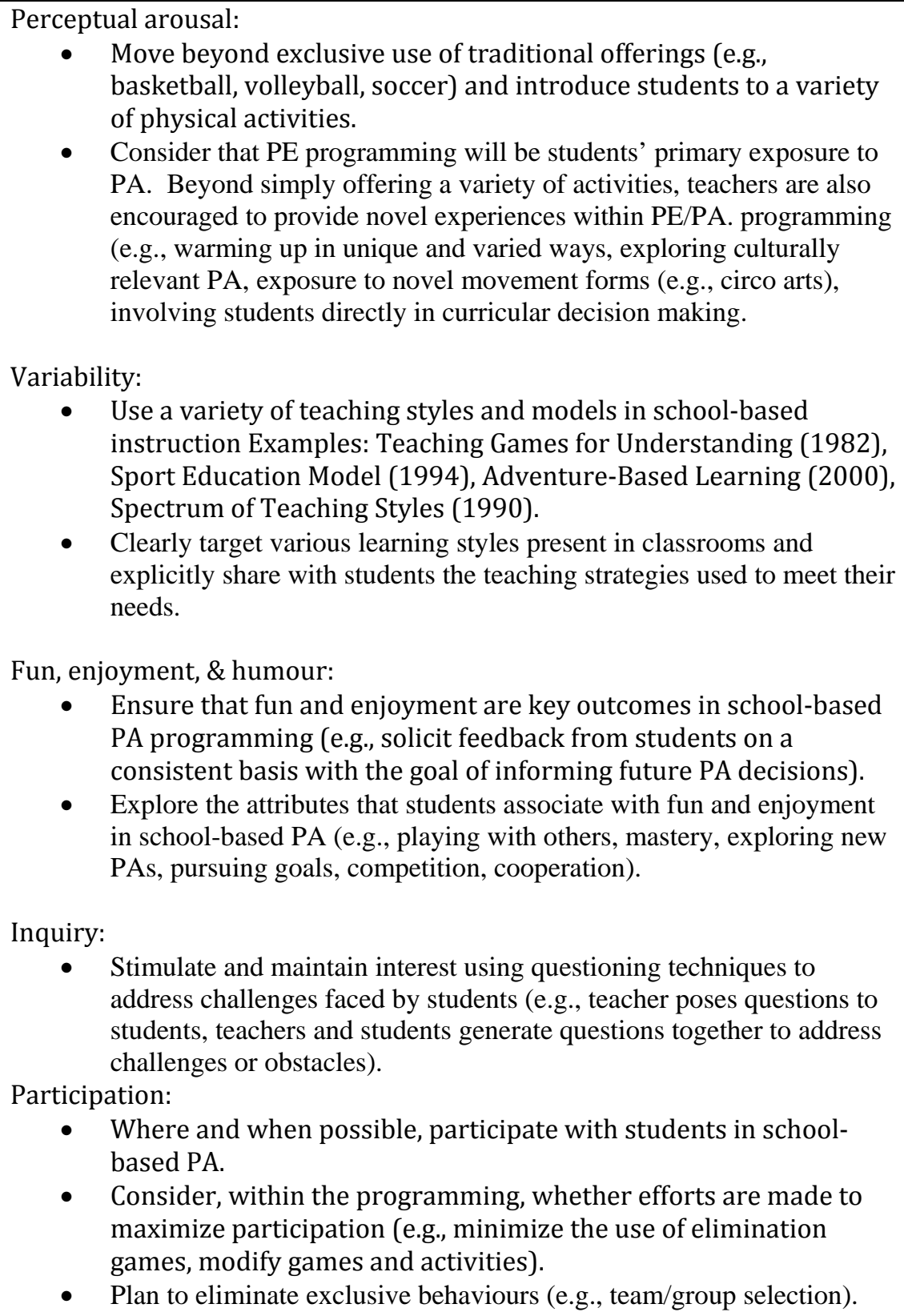 \\
\hline
\end{tabular}


School-based Physical Activity

Table 2

Finding Relevance in School-based PA

\begin{tabular}{|c|c|}
\hline $\begin{array}{l}\text { ARCS-sbPA } \\
\text { Conceptual } \\
\text { Category }\end{array}$ & Sample success strategies for school-based PA settings \\
\hline Relevance & $\begin{array}{l}\text { Experience: } \\
\text { Attempt, where possible, to help students see and make the } \\
\text { connections between existing knowledge, skills, strategies, and } \\
\text { abilities emphasizing transferability across a wide range of PAs (e.g., } \\
\text { catching in baseball is also like catching in Frisbee breathing } \\
\text { techniques in yoga can be used to help them manage their stress when } \\
\text { preparing for a test). } \\
\text { Goal orientation: } \\
\text { - Work with students to identify and develop personal goals } \\
\text { emphasizing the importance of their own personal aspirations } \\
\text { and growth across a wide variety of PAs. } \\
\text { At the start of units and lessons, consistently share learning } \\
\text { objectives that will guide school-based PA experiences. Doing so } \\
\text { can provide direction and rationale for student participation in } \\
\text { school-based PA programming. } \\
\text { Future usefulness: } \\
\text { Within daily teaching, teachers can help students make the } \\
\text { connections between learning through PA and the impact of that } \\
\text { learning on their current and future health and well-being (e.g., } \\
\text { learning to make healthy food choices is important because ..., } \\
\text { participating in regular PA is important because ..., learning and } \\
\text { playing with others is important because ..., exploring and } \\
\text { developing resiliency skills through PA can help me because ....). } \\
\text { - Attempt to line up programming and learning goals that meet the } \\
\text { Involve students in the curricular decision-making process. It stands } \\
\text { to reason that students will be more interested in participating in a } \\
\text { program of study where they have been consulted. Assumptions } \\
\text { regarding student needs and interest that are based on teachers' own } \\
\text { student experiences, inference, and intuition will likely fault short of } \\
\text { students' actual needs and interests. } \\
\text { needs of all students. Teachers can use the following four } \\
\text { questions to help guide their assessment of students' needs and } \\
\text { interests. } \\
\text { 1. Have I explored the value that students will place on this } \\
\text { lesson/activity/unit? } \\
\text { 2. Am I aware of students' interest in this lesson/activity/unit? } \\
\text { 3. Have I identified their concerns associated with participating } \\
\text { in the lesson/activity/unit prior to instruction? } \\
\text { 4. Do I know what my students are looking to take away from } \\
\text { participating in the lesson/activity/unit? }\end{array}$ \\
\hline
\end{tabular}


School-based Physical Activity

Table 3

With Confidence Comes Competence

\begin{tabular}{|c|c|}
\hline $\begin{array}{l}\text { ARCS-sbPA } \\
\text { Conceptual } \\
\text { Category }\end{array}$ & Sample success strategies for school-based PA settings \\
\hline Confidence & $\begin{array}{l}\text { Learning requirements: } \\
\text { - At the start of each class, clearly address the following points with } \\
\text { all students: } \\
\text { 1. Identify and explain the learning goals for the lesson/activity. } \\
\text { 2. Outline the specific criteria you will be using to assess student } \\
\text { learning in relation to the learning goals. } \\
\text { 3. Share upfront how you will be providing assistance and } \\
\text { enrichment for individual students. } \\
\text { Success: } \\
\text { - Success should be measured against developed and fixed criteria. } \\
\text { - Learning through physical activity should be scaffolded, } \\
\text { increasing the level of challenge as students progress. Teachers } \\
\text { should check in with students to ensure all are comfortable, safe, } \\
\text { and challenged by pace and complexity of learning. } \\
\text { Emphasize individual student growth and learning. School-based } \\
\text { PA teachers should endeavour to mitigate students' comparison } \\
\text { of progress and performance amongst students. } \\
\text { Provide students with multiple and varied opportunities to practice } \\
\text { and demonstrate their learning through physical activity. } \\
\text { Attributions: } \\
\text { - Help students make the connection between their efforts and } \\
\text { their success in meeting the specified criteria (e.g., use student- } \\
\text { centred and action-oriented language in descriptive feedback; } \\
\text { have students articulate their processes and actions used to } \\
\text { address or meet learning goals in class). } \\
\text { Put students in situations where they are in control of their } \\
\text { learning and assessment of their learning (e.g., use of peer- } \\
\text { teaching techniques, discovery learning, and analogical learning). }\end{array}$ \\
\hline
\end{tabular}


Table 4

Teaching to Celebrate Student Achievement

\begin{tabular}{|c|c|}
\hline $\begin{array}{l}\text { ARCS-sbPA } \\
\text { Conceptual } \\
\text { Category }\end{array}$ & Sample success strategies for school-based PA settings \\
\hline Satisfaction & $\begin{array}{l}\text { Intrinsic satisfaction: } \\
\text { - } \quad \text { Provide students with opportunities to teach what they have } \\
\text { learned to other students (e.g., use of peer-coaching). } \\
\text { Provide students with opportunities to demonstrate their learning in } \\
\text { authentic ways (e.g., using learned skills and strategies in game play, } \\
\text { allowing students to decide how they would like to demonstrate their } \\
\text { competencies using tasks they find meaningful). } \\
\text { - Take time to consider what students need in the way of positive } \\
\text { reinforcement (e.g., public praise, personal note or conversation, } \\
\text { positive reinforcement from peers) and provide individualized } \\
\text { reinforcement that supports students' efforts in progress and } \\
\text { performance. } \\
\text { Fairness: } \\
\text { Provide timely and consistent feedback to all students }\end{array}$ \\
\hline
\end{tabular}

\section{Motivation in Action and the Reflective Teacher}

A teaching orientation that is grounded in the identification of oneself as a teacher of students reflects the importance and value placed on the student at the centre of teaching and learning decisions (Barrett, 2013). In diagnostic assessments and planning, teachers should address the initial needs of students to ensure that their design and planning have considered both the learning and motivational needs of their students (Barrett, 2013). As a component of their ongoing formative assessment of student learning, teachers in schoolbased PA settings could monitor and provide feedback addressing student learning needs with motivation in mind. This formative assessment would provide teachers with valuable information related to student learning, and it could inform future teaching decisions targeting the specific needs of students. In recognition that student motivation in school- 
based PA settings can influence effort and achievement, the following three questions could be considered as part of the teachers' cycle of instruction:

1. How are the category-specific motivation strategies I have incorporated affecting student learning and participation?

2. Are there present concerns associated with student motivation in the lesson/activity/unit?

3. Within this cycle of instruction, have I checked in with students to address their concerns, interests, and goals associated with take-away learning?

Reflection, with the intent upon improving school-based PA experiences can be characterized as an active search for understanding—an inquiry stance guided by a moral obligation to help students find success (Larrivee \& Cooper, 2006). In Ontario, 21stcentury teachers are expected to be reflective practitioners. There is an expectation that teaching decisions will be informed by evidence, in particular assessments of student learning and achievement. Planning and instructional decisions are to be made based on the analysis of information gathered. Reflective teachers "spend a lot of time thinking about classroom interactions and consider both the intended and unintended consequences of their actions" (Larrivee \& Cooper, 2006, p. 5). Hence, teachers are encouraged to monitor students' responses to the successful motivation strategies of each category and evaluate the effectiveness of each strategy intervention.

\section{Conclusion}

Acknowledging the many barriers to the provision of school-based PA is easy. The more difficult task is moving beyond the identification and explanation of barriers toward 
potential solutions. This paper has attempted to highlight the need for and value of schoolbased PA from a health-intervention perspective, and provide a brief overview of some of the barriers affecting teachers of PA.

Additionally, this paper has suggested that practicing teachers must have a comprehensive understanding of students' motivational needs if they are to capably address challenges with student motivation in school-based PA environments. Intuitive understandings that rely on perceptions, inference, and teachers' personal experiences are not sufficient. Student motivation needs to be understood through an external, tangible, and systematic process to help teachers of school-based PA make evidence-based planning and teaching decisions.

To this end, this paper has proposed one potential macro planning and instructional solution to address a single barrier-the challenge associated with planning for student motivation in school-based PA settings. Specifically, it has analyzed Keller's (1987) ARCS model design process and categories as a potential solution and presented, with respect, a modified version, the ARCS school-based PA model (ARCS-sbPA), providing considerations and sample category success strategies that could be embedded in current school-based PA planning and instructional practices. The ARCS-sbPA model, inclusive of its categories and design process considerations, provides teachers an approach that could be integrated into existing instructional planning practices to support the development of school-based PA programming that is firmly grounded in learner motivation and needs. 
School-based Physical Activity

\section{References}

Alberta Education. (2008). Daily physical activity survey report, 2008. Retrieved from http://education.alberta.ca/media/756341/ dpasurveyreport.pdf

Ames, C. (1990). Motivation: What teachers need to know. Teachers College Record, 91, 409421.

Ames, C. (1992). Classrooms: Goals, structures, and student motivation. Journal of Educational Psychology, 84, 261-271.

Bandura, A. (1977). Social learning theory. Scarborough, ON: Prentice Hall.

Barrett, J. M. (2011). Teacher candidates' perceptions of the daily physical activity initiative and their emerging self-efficacy as daily physical activity instructors. (Doctoral dissertation). Available from ProQuest Dissertations and Theses database. (UMI No. 3459116)

Barrett, J. M. (2013). Beyond physical education: School-based physical activity programming. In D. Robinson \& L. Randall (Eds.), Teaching Physical Education Today (pp. 274-292). Toronto, ON: Thompson Educational Publishing.

Boiche, J. C., Sarrazin, P. G., Grouzet, F. M., Pelletier, L. G., \& Chanal, J. P. (2008). Students' motivational profiles and achievement outcomes in physical education: A selfdetermination perspective. Journal of Educational Psychology, 100, 688-701.

Bunker, D., \& Thorpe, R. (1982). A model for the teaching games in the secondary school. Bulletin of Physical Education, 10, 9-16.

Cosgriff, M. (2000). Walking our talk: Adventure based learning and physical education. Journal of Physical Education New Zealand, Special millennium issue: A tribute to teachers, 33, 89-98. 
Deci, E. L., \& Ryan, R. M. (1985). Intrinsic motivation and self-determination in human behavior. New York, NY: Plenum.

Doolittle, S. P., Dodds, P., \& Placek, J. (1993). Persistence of beliefs about teaching during formal training of preservice teachers. Journal of Teaching in Physical Education, 12, 355-365.

Douglas, D., Lu, C., \& Barrett, J.M. (2013). Developing physical activity habits in schools for active lifestyle among children and adolescents. Manuscript submitted for publication.

Dwyer, J. J. M., Allison, K. R., LeMoine, K. N., Adlaf, K. M., Goodman, J., Faulkner, G. E. J., \& Lysy, D. C. (2006). A provincial study of opportunities for school-based physical activity in secondary schools. Journal of Adolescent Health, 39, 80-86.

Good, T. L., \& Brophy, J. E. (2008). Looking in classrooms (10th ed.). Boston, MA: Allyn \& Bacon.

Gurvitch, R., \& Metzler, M. W. (2009). The effects of laboratory-based and field-based practicum experience on pre-service teachers' self-efficacy. Teaching and Teacher Education, 25, 437-443.

Hagger, M.S., Chatzisarantis, N.L.D., Barkoukis, V., Wang, C.K.J., \& Baranowski, J. (2005). Perceive autonomy support in physical education promotes leisure-time physical activity intentions and behavior: A trans- contextual model. Journal of Educational Psychology, 95, 784-795.

Hill, G., \& Brodin, K. L. (2004). Physical education teachers' perceptions of the adequacy of university coursework in preparation for teaching. Physical Educator, 61, 75-87. 
School-based Physical Activity

Janssen, I., \& LeBlanc, A. G. (2010). Systematic review of the health benefits of physical activity and fitness in school-aged children and youth. International Journal of Behavioral Nutrition and Physical Activity, 7, 1-16.

Kahn, E., Ramsay, L., Brownson, R., Heath, G., Howze, E., Powell, K., \& Corso, P. (2002). The effectiveness of interventions to increase physical activity: A systematic review. American Journal of Preventive Medicine, 22, 73-107.

Keller, J. M. (1979). Motivation and instructional design: A theoretical perspective. Journal of Instructional Development, 2, 26-34.

Keller, J. M. (1983). Motivational design of instruction. In C. M. Reigeluth (Ed.), Instructional design theories and models: An overview of their current status. Hillsdale, $\mathrm{NJ}$ : Lawrence Erlbaum.

Keller, J. M. (1987). The systematic process of motivational design. Performance \& Instruction, 26, 1-8.

Keller, J.M. (2000, February). How to integrate learner motivation planning into lesson planning: The ARCS model approach. Paper presented at VII Semanario, Santiago, Cuba. Retrieved March29, 2008, from http://mailer.fsu.edu/ jkeller/Articles/Keller\%202000\%20ARCS\%20Lesson\%20P lanning.pdf

Keller, J. M. (2008). First principles of motivation to learn and e3-learning. Distance Education, 2, 175-185.

Keller, J. M., \& Suzuki, K. (2004). Learner motivation and e-learning design: A multinationally validated process. Journal of Educational Media, 29, 229-239. 
Larrivee, B., \& Cooper, J.M. (2006). An educator's guide to teacher reflection. Boston, MA: Houghton Mifflin.

Lodewyk, K. R., \& Pybus, C. M. (2013). Investigating factors in the retention of students in high school physical education. Journal of Teaching Physical Education, 32, 61-77.

Ministry of Education, Ontario. (2005). Policy/program memorandum No. 138. Retrieved from www.edu.gov.on.ca

Ministry of Education, Ontario. (2010). The Ontario curriculum Grades 1-8: Health and physical education. Toronto, Canada: Ministry of Education.

Ministry of Education, Ontario (2011). Learning for all: A guide to effective assessment and instruction for all students, kindergarten to grade 12. Retrieved from http://www.edu.gov.on.ca/eng/general/elemsec/speced/learningforall2011.pdf

Morgan, P., \& Bourke, S. (2005). An investigation of preservice and primary school teachers' perspectives of PE teaching confidence and PE teacher education. ACHPER, Healthy Lifestyles Journal, 52, 7-13.

Morgan, P. (2008). Teacher perceptions of physical education in the primary school: Attitudes, values and curriculum preferences. Physical Educator, 65, 46-56.

Morgan, P., \& Hansen, V. (2008). Physical education in primary schools: Classroom teachers' perceptions of benefits and outcomes. Health Education Journal, 67, 196207.

Mosston, M., \& Ashworth, S. (1990). The spectrum of teaching styles: From command to discovery. New York, NY: Longman.

Ntoumanis, N. (2001). A self-determination approach to the understanding of motivation in physical education. British Journal of Educational Psychology, 71, 225-242. 
Ntoumanis, N. (2005). A prospective study of participation in optional school physical education based on self-determination theory. Journal of Educational Psychology, 97, 444-453.

Public Health Agency of Canada (2011). Obesity in Canada: A joint report from the Public Health Agency of Canada and the Canadian Institute for Health Information. Retrieved from http://www.phac-aspc.gc.ca/hp-ps/hl-mvs/oic-oac/assets/pdf/oicoac-eng.pdf

Sallis, J., Cervero, R., Ascher, W., Henderson, K., Kraft, M., \& Kerr, J. (2006). An ecological approach to creating active living communities. Annual Review of Public Health, 27, 297-322.

Shields, M., Carroll, M.D., Ogden, C.L. (2011). Adult Obesity Prevalence in Canada and the United States. Retrieved from http://www.cdc.gov/nchs/data/databriefs/db56.htm

Siedentop, D. (1994). Sport education: Quality physical education through positive sport experiences. Champaign, IL: Human Kinetics.

Sorensen, M., \& Gill, D. (2008). Perceived barriers to physical activity across Norwegian adult age groups, gender and stages of change. Scandinavian Journal of Medicine \& Science in Sports, 18, 651-663.

Taylor, I. M., Ntoumanis, N., Standage, M., \& Spray, C. M. (2010). Motivational predictors of physical education students' effort, exercise intentions, and leisure-time physical activity: A multilevel linear growth analysis. Journal of Sport \& Exercise Psychology, 32(1), 99-120. 
School-based Physical Activity

World Health Organization. (2010). Global recommendations on physical activity for health. Retrieved from http://whqlibdoc.who.int/publications/ 2010/9789241599979 eng.pdf?ua=1

Yli-Piipari, S., Wang, J. C., Jaakkola, T., \& Liukkonen, J. (2012). Examining the growth trajectories of physical education students' motivation, enjoyment, and physical activity: A person-oriented approach. Journal of Applied Sport Psychology, 24, 401417.

Zhang, T. (2009). Relations among school students' self-determined motivation, perceived enjoyment, effort, and physical activity behaviors. Perceptual and Motor Skills, 109, 783-790. 